\title{
6
}

\section{German Moravian missionaries on western Cape York Peninsula and their perception of the local Aboriginal people and languages ${ }^{1}$}

\section{Corinna Erckenbrecht}

From 2004 to 2007, I conducted in-depth research about the German physical anthropologist and collector Hermann Klaatsch (1863-1916), who travelled around Australia from 1904 to 1907. This research examined newly available personal and scientific documents (Erckenbrecht 2010). ${ }^{2}$ Klaatsch was a medical doctor, comparative anatomist and Darwinist, who firmly believed in the origin of species by natural selection as outlined in Darwin's famous book in 1859. By the end of the nineteenth century, more scientists believed that similar selection processes must have caused the human species to evolve; however, no one could say then where the development of humankind had taken place in prehistoric times. Thus, Klaatsch and many of his fellow anthropologists around the turn of the nineteenth century felt that more world-changing evidence for the new theory would soon be found. Eugéne Dubois, for instance, went to Indonesia specifically to look for archaeological sites and human fossils, because the tropics were seen as a likely place for these kinds of discoveries. ${ }^{3}$

\footnotetext{
I would like to thank Geoff Wharton for his comments on an earlier draft of this chapter.

The documents are kept by the Klaatsch family in the United States.

Africa, however, was not on anyone's list yet and it was hardly mentioned in the literature of that time.
} 


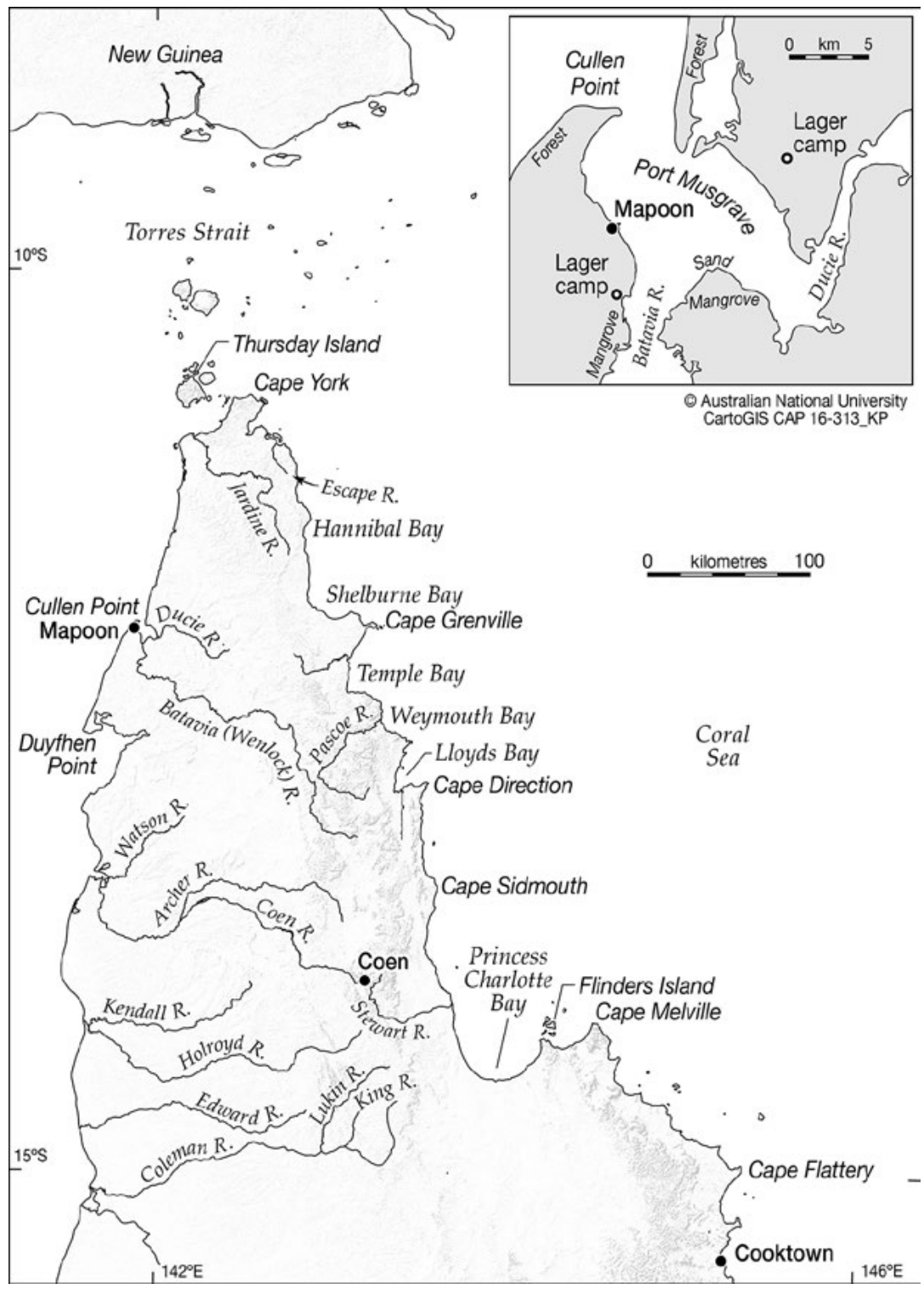

Map 6.1 Location of Mapoon Mission on Cape York Peninsula, 1892.

Source: CartoGIS, The Australian National University, based on a historical map drawn by the missionaries in 1892 and first published in the Periodical Accounts Relating to the Foreign Missions of the Church of the United Brethren (1894: Vol. 2, No. 17, p. 263). 
Klaatsch's friend and colleague Otto Schoetensack (1850-1912) was convinced that the anthropogenesis had in fact taken place in Australia in prehistoric times (Schoetensack 1901, 1902, 1904), thus following some indications that British naturalist Thomas Huxley had mentioned in his book (Huxley 1863). Schoetensack's poor health prevented him from going on long overseas journeys. His younger friend Klaatsch, however, was prepared to go as soon as the opportunity arose. In August 1903, Klaatsch met a wealthy German representative of a north Queensland mining company, Francis E. Clotten, who planned a journey to Australia to inspect his mine and invited Klaatsch to accompany him. They left Europe in February 1904 and in March arrived in Brisbane, where Klaatsch remained for a few months. He was introduced to Walter E. Roth, the north Queensland protector of Aborigines at that time, and the two scientists became good friends. In his capacity as protector, Roth paid regular visits to various settlements, mission stations and Aboriginal camps in north Queensland using the government sailboat Melbidir. When Roth was asked to go to Western Australia in 1904 for an investigation into the mistreatment of Aboriginal people, he allowed Klaatsch to use the Melbidir on his behalf. Thus, Klaatsch went on a four-month journey to the Gulf of Carpentaria and visited, among other places, the Presbyterian mission station at Mapoon on western Cape York Peninsula at the end of July and the beginning of August 1904. Mapoon was established for the Presbyterian Church by Moravian missionaries James Ward and Nicolaus Hey in 1891 (see below).

When Klaatsch arrived at Mapoon, preparations were under way for the founding of another station at the Archer River, later called Aurukun. The new German missionary, Arthur Richter, was to establish the station. Klaatsch, being a guest at Mapoon, was invited to go along to the Archer River as well. There, Klaatsch was an eyewitness to the landing at the shore and the carrying of all provisions to the spot where the mission station was going to be established and where the first house was to be built. He took photographs of these scenes and also described it vividly in his notebooks and diaries (see Erckenbrecht 2010: 69ff). 


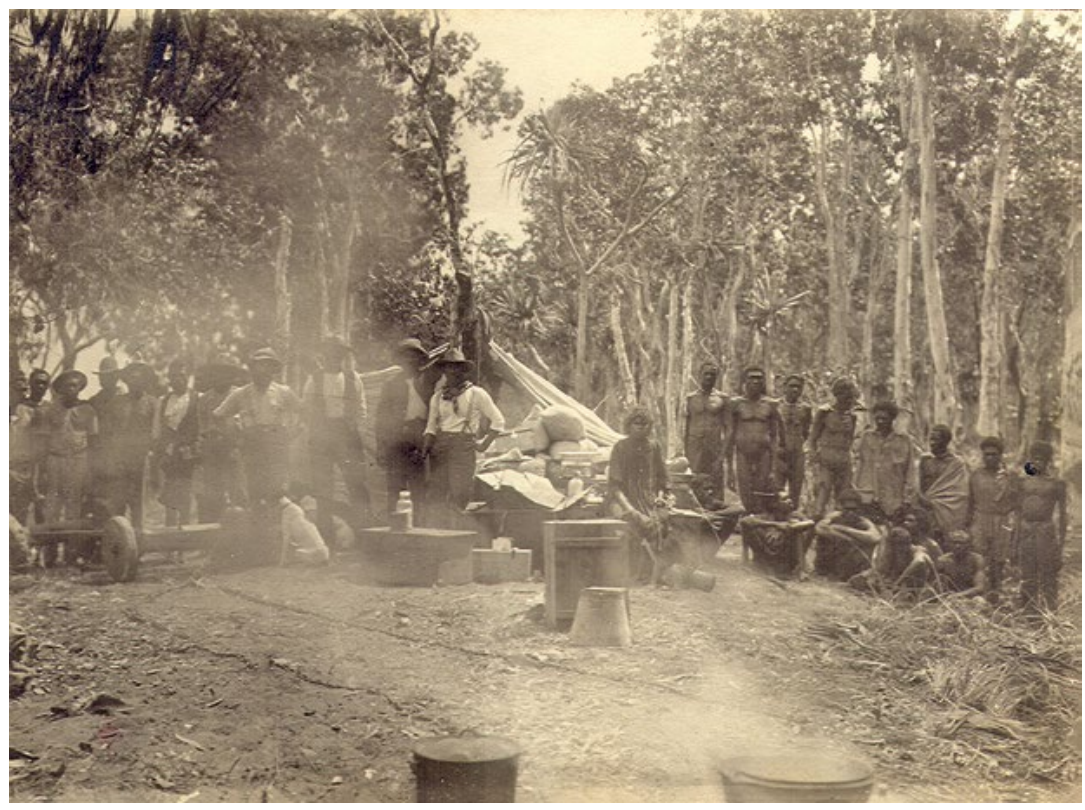

Plate 6.1 Missionaries and their helpers at the landing place on their first day at the Archer River in August 1904.

In his notes, Klaatsch described many of the people in this photo, including an Indigenous 'Mamoos'. The same photo exists in the Moravian Church Archives, thus proving the contacts between Klaatsch and the Moravians.

Source: Hermann Klaatsch, 4 August 1904. Scan of historical photograph, Klaatsch family archive, USA.

These connections between a German scientist and traveller and the German Moravian missionaries in north Queensland brought me in touch with the Moravian Church Archives in Herrnhut, Saxony. I discovered their extensive and unique records, and especially their collection of historical photographs from north Queensland. The Herrnhut Museum of Ethnology also keeps an ethnographic collection by the German missionaries from north Queensland (as well as from Victoria, where the Moravians ran mission stations for several decades until 1908).

Following this first visit to Herrnhut, I planned to conduct research at the museum and archives, and, after having secured funding from the German Research Foundation (DFG) for a two-year research project, I started working at Herrnhut in November 2013, also moving to the Upper Lusatia region in Saxony for this project. Living in the very 
place where the missionaries had lived and where they had attended the Moravian Mission College in the nearby town of Niesky gave me additional inspiration for my research.

\section{My research project: Method and focus}

My research focuses on the 'Early missionary and colonial perspectives on the Indigenous cultures and languages of western Cape York Peninsula, Australia, and the documentation of the cultural changes in this region based on written documents, ethnographic artefacts and historical photographs. ${ }^{4}$ Originally, I intended to cover the whole period of the Moravian-run mission stations in north Queensland, from 1891 to 1919,5 for all three stations (Mapoon, Weipa and Aurukun). But the Moravian Church Archives resources proved to be too numerous for just two years of research (including publishing the results in a book). Given this background, I decided to focus on the first five years of culture contact between the missionaries and the local Aboriginal people, from 1890 to 1895 . This was the time of the initial contact of the German and British missionaries with the local Indigenous population at Cullen Point, later called Mapoon. The written records of this time- that is, the letters and reports that the missionaries wrote home to their mission board, their former mission college and friends and to the editorial boards of the Moravian journals-provide a fascinating insight into this first contact situation and the brethren's feelings, perceptions and efforts, and also doubts.

Moreover, the head of the mission station, James Ward, died in 1895, possibly from typhoid fever. The rest of the staff, also sick and demoralised by this experience, left the station temporarily to recover in a cooler climate in southern Australia. For all of them, it was a time to look back and review what had happened. This break was also the time for me to stop my research at 1895 and look back. I decided that the best time span for my research would be these early days of the mission. This was the period of various comparable written sources, when both Ward and Hey wrote their letters home. Their varying first impressions and thoughts to

\footnotetext{
4 This is the English title of my research proposal.

5 In 1919, the Moravians left north Queensland for various reasons and the Presbyterian Church took over with its own staff.
} 
different addressees, their various perceptions and documentations, trials and errors, their feelings of desperation, but also of joy, and critiques were contained in these first years.

Almost all of these sources are written in German, most of them in old German script. They are not well known in Australia. So, my idea was to provide a unique contribution to north Queensland anthropology and mission history, and to 'excavate' and transcribe these early German sources to make them accessible for research and study-and, of course, for the personal use of the local Aboriginal people today as well.

But the written sources are just one part of the material, as mentioned above. The two other parts are the collection of historical photographs at the Moravian Church Archives and the collection of ethnographic artefacts at the Museum of Ethnology. Accordingly, I am interested in the triangulation of all three sources, studying them together at the same time. Further sources from the United Kingdom and, of course, Australia are included. I am especially interested in finding overlapping information to understand the meaning, intention and background of them all. This includes the question, for instance, of why certain photographs were taken in the first place. What are the photos about? What do they depict? How, by whom and in which context were they later used? Which captions were given by the missionaries themselves, by their wives or, later, by the brethren in Herrnhut? All these questions and their answers provide new and fascinating insights.

While conducting this research I am, of course, also interested in what can be said about the local Aboriginal society at that time. However, all sources are by the missionaries only and what they saw in the Aborigines or thought worthwhile to write home about them. There are hardly any relevant firsthand quotes by Aboriginal people themselves in those documents. So one has to be very careful in examining and evaluating the content of the text (or photos). The sources carry a palimpsestsomething that shines through, but cannot be read easily or straight away. Rather, it has to be carefully identified, extracted, interpreted and assessed. Therefore, I would like to make it very clear in the theoretical, methodological and also practical approach of my research that I can produce results only about the Moravian perception of the Indigenous world in north Queensland: what they had on their mind when they came to Australia and whether or not they were able to understand what they saw and heard. It's about their perception on the basis of their specific background. 


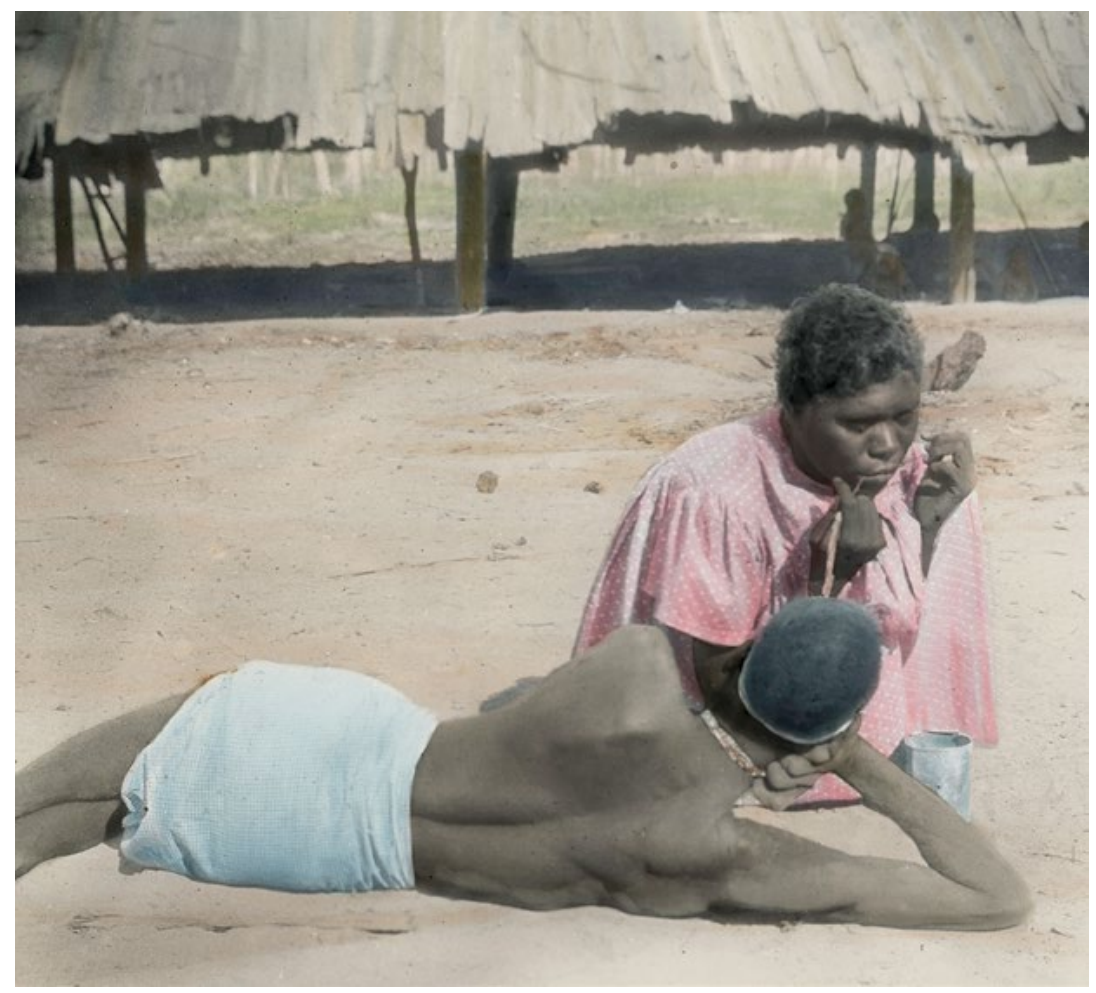

Plate 6.2 An example of a historical photograph in the Moravian Church Archives with an unclear motive.

Further research revealed that it can be compared with scenes published by Roth (1903: 38 , pl. 40) showing the use of 'sucking strings', thus depicting a healing ceremony or medical treatment. This kind of treatment was described in the missionaries' letters.

Source: Collection, Moravian Church Archives, Herrnhut, Germany, LBS 02843_C_2R_56-No_24.

\section{Moravia and Moravian Church history}

Moravia is a large geographic region in the eastern part of what is now the Czech Republic. The largest city is Brno. The region takes its name from the main river running through it, the Morave. Moravia is just a region and was never a nation-state. Thus, people from Moravia-Moravians in general—such as the well-known Sigmund Freud (Austrian), Oskar Schindler (German) and Ivan Lendl (Czech), belong(ed) to different states, nationalities and/or empires in the past. Together with Bohemia, Moravia forms the core region of the Czech Republic. 
The Moravian Church originated in this region (as well as in neighbouring Bohemia). It is a pre-Reformation Protestant denomination dating back to the fifteenth century. Its members are followers of Jan Hus (1370-1415), a very influential Czech reformer. Jan Hus (English: John Huss) was a professor of theology and head of the university in Prague. He expressed ideas similar to those of Martin Luther, who came 100 years after him, including translating and teaching the Bible in the native tongue, criticising the sins and low morals of the monks and the clergy, opposing the sale of indulgences, emphasising the importance of the holy script only ('sola scriptura') and accepting laypeople to receive communion. Therefore, the chalice used in Holy Communion is one of their symbols.

Jan Hus was burnt at the stake for his beliefs 600 years ago (on 6 July 1415) at the council in Constance. This had far-reaching consequences. War broke out in the following years (the Hussite wars) and his followers were persecuted. They split into several groups with different aims, beliefs and politics, which are beyond the scope of this chapter to explain. One group re-formed officially in 1475, 50 years after Hus's death, and it was called the Unity of the Brethren or the Bohemian Brethren. This was the beginning of the new and independently organised Moravian Church.

In 1720, Count Nicolaus Ludwig Zinzendorf (1700-60) bought an estate at Berthelsdorf in the Upper Lusatia region in Saxony where he offered sanctuary to the Bohemian and Moravian Brethren in 1772, after their continuing persecution. Following their arrival, they cleared the woods and built a new village called Herrnhut ('under the hat of the Lord' or 'Lord's watch'). There was a renewal and reunification and, in 1732, after some quarrels in 1727, they decided to start their mission work again.

\section{Moravian missionary activity and mission ethics}

The Moravians first worked with African slaves in the West Indies (St Thomas), because Count Zinzendorf had heard sad stories of the lot of these slaves through a personal acquaintance with a black servant from St Thomas at the court of the Danish king in Copenhagen. Zinzendorf, himself an active member of the religious community and later bishop of the United Brethren, brought this slave with him from Copenhagen to Herrnhut in 1731. This sparked the enthusiasm for mission work, and, in 1732, the first brethren went to St Thomas. Later, the missionaries went 
to many other and quite different countries, such as Suriname, Labrador, Nicaragua and Tibet, to name just a few. They did not follow the paths of German — or British—colonial rule, but acted on the needs or requests they felt necessary to address. Altogether, they were active in 32 countries worldwide.

In their mission work, they were quite specific about which ethnic or cultural group they would like to address. In Labrador, for instance, they were only interested in the Inuit-not in the local tribes of Native Americans who also lived there. In Suriname in South America, they were interested in some coastal tribes, but also escaped slaves in the interior, called Marrons. In Nicaragua, they worked with several tribes on the remote Atlantic coast. Thus, they paid attention to remote ethnic and cultural groups at a time and in places when nobody else was interested in them. This is one of the reasons the Moravian Church Archives are so extremely valuable today and why they are consulted by visitors and researchers from all over the world.

Moravian mission ethics included to work with the poorest of the poor, to go where no one else wants to go, to live with people with whom no one else wants to live and to really love the mission work and really love the people. This caused great concern for the Moravian missionaries at Mapoon and also their wives, because they felt unsure as to whether they really loved Aboriginal people with all their heart. They remarked on their feelings and doubts in this regard in their letters. For them, it was a prerequisite for their mission work, no matter where they went.

At Niesky, another Moravian settlement near Herrnhut, there was a mission school at which Moravian teachers trained future missionaries. Nicolaus Hey went to school there for two years before he was called to the mission field in Australia. The school had a wide variety of subjects being taught, but it focused mainly on instructing its pupils in practical skills such as gardening and farming, but also, for instance, photography, especially since the head of the school in Hey's time, Hermann Kluge, took a special interest in it. 


\section{Formative influences for Moravian thought and identity}

The Moravian Church and its missionaries were heavily influenced by their history and experiences, which I have tried to outline above and which I would like to summarise briefly as follows. They were a persecuted religious minority in exile, having successfully survived in a foreign and hostile environment through brotherly love and unity, which provided spirit, strength and endurance. This was based on the Protestant work ethic and a belief in education and lifelong learning. They also applied a surprisingly progressive working scheme: unmarried brothers and sisters could live on their own in separate houses and work independently in a communal way. Thus, progress and modest prosperity were achievable through a rural yet industrious lifestyle. And, last but not least, they had a centuries-long history of successful missionary work.

\section{Moravians in Australia: Moravians in north Queensland}

There had been Moravian missionaries in Australia since 1849. Charles La Trobe (1801-75), Superintendent of the Port Phillip district of New South Wales and then Lieutenant-Governor of Victoria, had invited Moravian missionaries to Australia. The La Trobe family belonged to the British branch of the Moravian Church. The Moravian missionaries tried to set up mission stations at several places in Australia. The first attempts were made in Victoria (at Lake Boga in 1851, Ebenezer in 1859 and Ramahyuck in 1864) and in northern South Australia, at Kopperamana and Killalpaninna (1866-68), following the ill-fated Bourke and Wills expedition. But these stations were given up after only a few months or years. ${ }^{6}$ The mission station with the longest duration was Ramahyuck and the main missionary there was Friedrich August Hagenauer (1829-1909), who ran the station for many decades, until 1908.

6 See the Missionary Atlas published by the Mission Board (Missionsdirektion 1895, 1907), and missionary Gottlieb Meißel's fascinating report (1898) — and also his drawings_of his time in northern South Australia. His subsequent travels around the world to Jamaica, where he was going to team up with other Moravian missionaries, are also fascinating. Felicity Jensz (see e.g. 2007, 2012) undertook extensive research about the Moravians in Victoria. 
In 1885, Hagenauer was asked to travel to north Queensland to assess the prospects of future mission work there. He wrote a report about this trip in 1886 called 'Notes of a missionary journey to north Queensland 1885' (Hagenauer 1886). However, Hagenauer came only as far as the Bloomfield River (Vilele plantation) on the east coast of Queensland and was never at the western Cape York Peninsula or Mapoon.

The British colony of Queensland was separated from New South Wales in 1859 . By the 1880 s, the Cape York Peninsula experienced the extension of goldmining and pastoralism. Conflicts broke out between the local Aboriginal people and pastoralists over the various uses of land, food, cattle and water. Many problems arose and many atrocities were committed against the Aboriginal people, which have been documented by Australian historians such as Rosalind Kidd (1997). Frequent calls by trepang, pearl and bêche-de-mer boats looking for new crew also added to a major upheaval in the living conditions of coastal Aborigines through long absences, the introduction of diseases and high death rates from tuberculosis onboard crowded sailing luggers. However, north Queensland and especially the Cape York Peninsula were still seen as quite well populated by Aboriginal people (in contrast with Victoria, where Hagenauer was constantly facing the closure of the mission station due to a steady decrease in the number of people living there). Therefore, the Presbyterian Church of Australia eventually decided to establish an Aboriginal mission in north Queensland and asked the Moravian Brethren in Herrnhut for suitable brothers to be sent over. The decision was first made in 1886 and, in 1890, the Moravians were contacted in Germany.

The Moravian Mission Board accepted this request and chose two brethren, according to the Australian Presbyterian Church wishes: one should be a good farmer, the other should be English or at least able to communicate fluently in English so as to easily handle all negotiations and correspondence in Australia. Accordingly, one British and one German brother were chosen (see below).

John Douglas (1828-1904), government resident at Thursday Island and a former premier of Queensland, was a crucial supporter of the establishment of an Aboriginal mission station in north Queensland. Two delegates of the Presbyterian Church, Reverends Hardie and Robinson from Melbourne, travelled to north Queensland, and, together with John Douglas, in July 1891, they went on a prospecting tour along the west coast to select the site for the future mission station. 
At that time, the Moravian missionaries had already arrived in Melbourne. They still believed, as they had been told, that they were going to be sent somewhere on the east coast of north Queensland next to white settlements (as Hagenauer had suggested) and were very surprised when Douglas and the Presbyterian delegates decided on the west coast at short notice.

Douglas remained a very influential political and practical supporter of the Moravian Brethren until his death in 1904. Without him, the missionaries would not have survived. Therefore, it is easy to understand why there is a photograph of John Douglas in the Moravian Church Archives photograph collection from north Queensland.

\section{The first missionaries in north Queensland and their background}

The first missionaries at Mapoon were James G. Ward (1857-95), a Jamaican-born son of a British Moravian missionary, and his Irish wife, Mathilda Ward, née Barnes. Ward came to Europe at the age of eight and visited the Moravian schools in England and Germany before settling in Northern Ireland (at Ballinderry near Belfast). Nicolaus Hey (1862-1951) was from a small village called Dörrenbach near Bergzabern, Palatinate, and his wife was Mary-Anne (Minnie) Hey, née Barnes, the sister of Mathilda. ${ }^{7}$

Neither couple knew anything about Australia, the Aboriginal people or the place where they were going to start the mission. They had heard only rumours or clichés. On their arrival in Melbourne, they were met by Friedrich Hagenauer and, a few weeks later, they were taken to his mission station, Ramahyuck, for a visit. Nicolaus Hey reported when he saw Aboriginal people and a Moravian mission station in Australia for the first time: 'I am not able to express my feelings that overwhelmed me at the first sight of the mission station.'

7 Before departing for Australia, Hey spent several months with the Wards in Ballinderry to learn English. Here, he met his future wife, the sister of Mathilda Ward, who played the organ at the local church. The Moravian missionary at the second station, Weipa (established in 1898), was Edwin Brown from England, and the Moravian missionary at the third station, Aurukun (1904), was Arthur Richter.

8 'Ich bin nicht im stande meine gefühle auszudrücken, die ich beim ersten Anblick der Station empfand', Letter No. 6(2) from Hey to the Mission Board from Melbourne, 21 August 1891, p. 3, Moravian Church Archives, Herrnhut, Saxony (translation by Anna Kenny). 


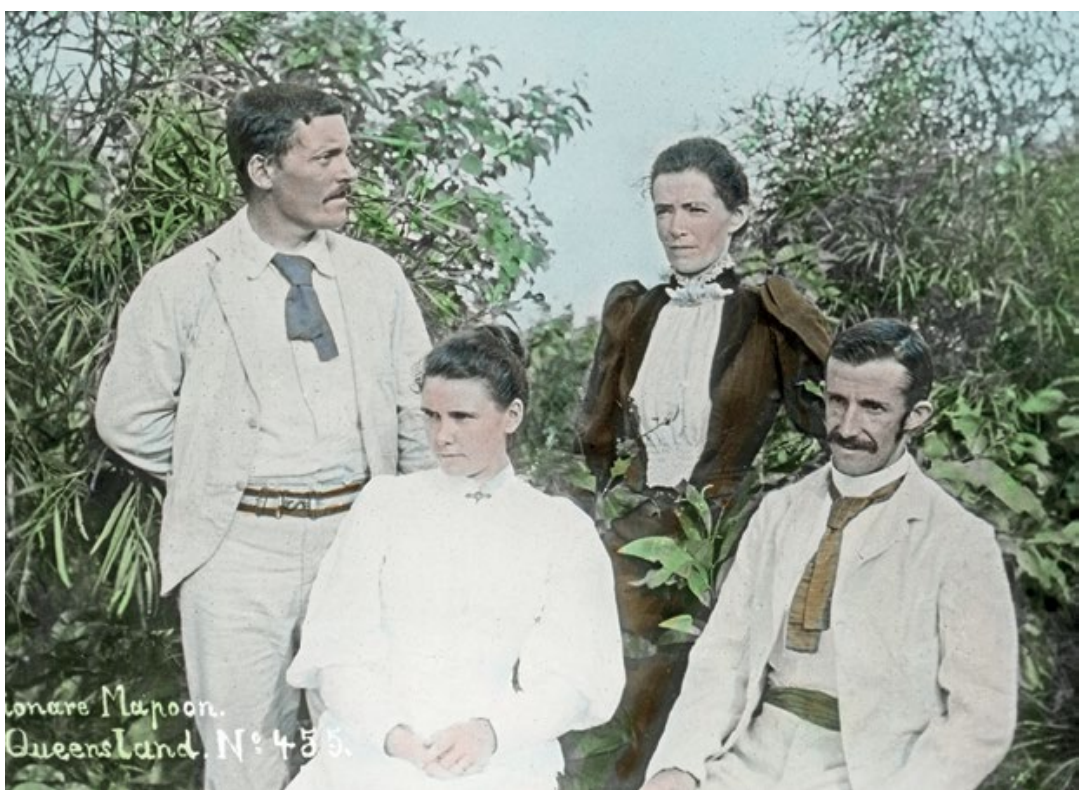

Plate 6.3 The two missionary couples at Mapoon.

Standing at the back: James Ward (1857-94); Mary-Anne Hey, née Barnes (1869-1970). Sitting in front: Mathilda Ward, née Barnes (1861-1953); Nicolaus Hey (1862-1951). This well-known photo has - as a paper print-handwritten colouring instructions on the back, but no year. It must have been taken in 1893 or 1894 .

Source: Collection, Moravian Church Archives, Herrnhut, Germany, LBS_00455_C_1R_52-No_68.

In addition to taking part in all kinds of practical work at the station and attending the church services, Hey and Ward were shown such things as boomerang throwing by the Aborigines. Later, in north Queensland, Ward was very surprised that the Aboriginal people had no boomerangs at all, which made him wonder whether perhaps the Cape York Aborigines were a complete 'swindle'. He used this particular word and it was also used later in the Moravian journals as a headline for the latest news from north Queensland:

No Boomerangs. The Menti. In one respect the blacks about here are a swindle. We always heard so much about the boomerang at home. We saw the Victorian blacks use it, but these blacks have no such thing. Nor have they a shield. Their only weapons are light or heavy spears, and the 'menti', an instrument for giving greater force to the spear when thrown. This serves for warding off the spears of their enemies in the fight as well.?

9 Moravian Missionary Reporter and Illustrated Missionary News, III(8)(NS)(August 1893), p. 59. 


\section{Their unpublished records: Letters, photographs and artefacts}

The two Moravian Brethren wrote regular letters to the Mission Board in Herrnhut, and Nicolaus Hey also wrote long letters to his teacher at the mission college at Niesky. He included photographs and sketch maps he had drawn. Both missionaries also wrote letters to the editorial boards of the Moravian journals such as the Periodical Accounts Relating to the Foreign Missions of the Church of the United Brethren, ${ }^{10}$ the Moravian Missionary Reporter and Illustrated Missionary News, the Moravian Messenger and the German Missions-Blatt der Brüdergemeine. Sometimes, personal letters to friends, including those written by the missionaries' wives, were published in these journals. ${ }^{11}$

Ward and Hey wrote about their daily life, their work and experiences, their establishment of a school and an orphanage ${ }^{12}$ and the building of the first church, as well as many other things, including their problems with the Queensland authorities. Of course, descriptions of their attempts to put the Christian message across formed a major part of their correspondence. They also talked about their difficulties in learning the local Indigenous language(s). In addition, they were also asked by the Mission Board to answer specific questions, such as how many and which

10 Printed for the Brethren's Society for the Furtherance of the Gospel among the Heathen in London.

11 All these published letters, however, were slightly altered by the editors without pointing this out. The quotation marks placed by the editors indicating the beginning and ending of quotes create the impression that these paragraphs are direct citations, but they are not. So, these secondary sources have very limited value, in contrast with the original letters.

12 The missionaries established an orphanage in the early stages of the mission settlement. It began when John Douglas, government resident at Thursday Island, brought three orphans to Mapoon in October 1892. He thought this was a good idea because they had no home and no one to look after them. The missionaries, on the other hand, were willing to start an orphanage on the spot (the brethren in Germany were surprised by this development). They built a grass house on a sand hill for the orphanage, which was completed on 30 October 1892. The missionaries then formed a family from the orphans: a teenage girl and two young boys, still children. The missionaries married the teenage girl to an Aboriginal man at Mapoon, and the two young boys were given to them as if they were their children. The young Aboriginal couple was also supposed to act as the wardens or heads of the orphanage and of all the children who would enter the orphanage in the future. The orphanage was an unstable institution at first and the young couple later split. Nevertheless, the idea and intentions were genuine, and it was officially mentioned as being the orphanage. The sources for the whole story can be found in several letters by Hey and Ward, one of the more relevant of which is No. 58 by Ward to the Mission Board, written in October 1892 from Cullen Point (ref. no. R.15.V.II.B.3.a.2, Moravian Church Archives). 
tribes lived around the station, their names and their languages. As Ward's and Hey's knowledge of these issues was quite poor in the beginning, their answers were not extensive or reliable in the first years.

The two brethren had quite different styles of writing. Hey often used his diary as the basis for his reports about events over long periods between letters; he was more systematic, albeit somewhat unsure and apparently ill at ease about writing, for instance, to the honourable elders of the church. After all, he was just a farmer. Ward, who had already worked as an ordained minister in Ireland, wrote more spontaneously and emotionally, but in a scholarly fashion, about events that had just happened. He also expressed more self-assurance and an ability to deal with conflictsin many cases, expressing independent opinions.

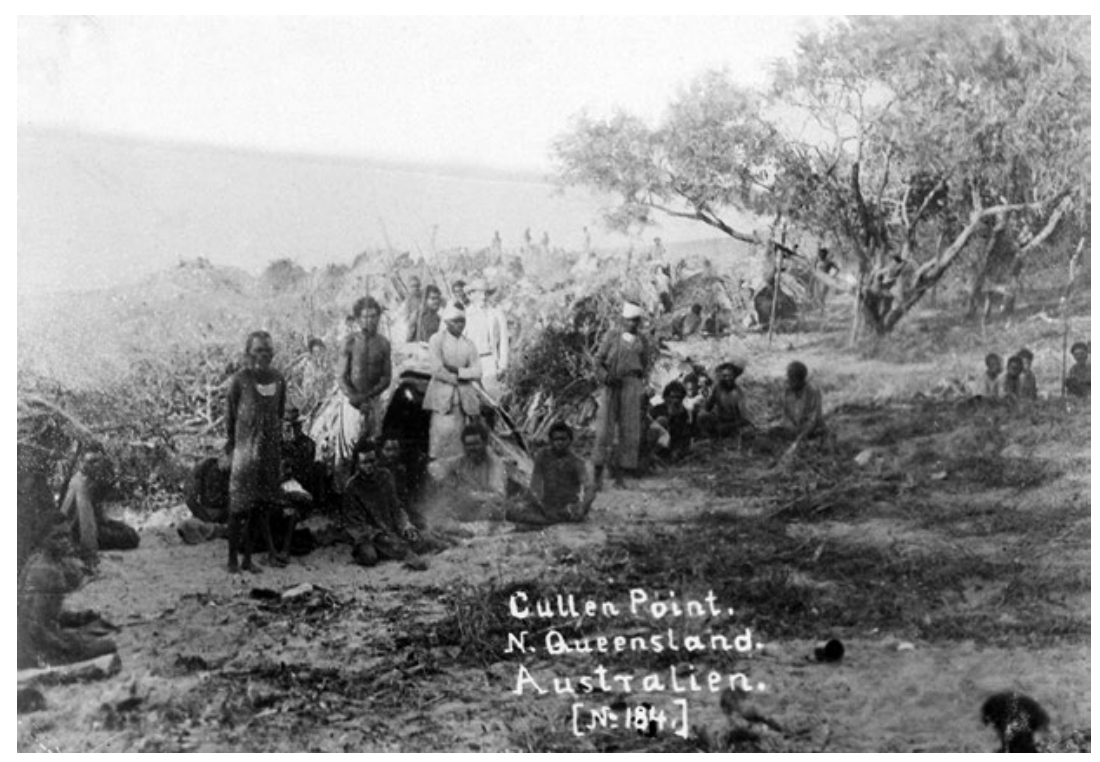

Plate 6.4 One of the very first photographs taken at Mapoon, showing an Aboriginal camp at the seashore. It was taken by a visiting boat captain, Mr Smith, in the second half of May 1892.

Source: Collection, Moravian Church Archives, Herrnhut, Germany, LBS_00184_B.

Most of the Moravian missionaries took photos (and, prior to the availability of photography, they did drawings and paintings), documenting one way or the other their mission stations and the local Indigenous people. As mentioned above, Hey and Ward in particular were asked by the head of the mission school to take photos. There was also a Moravian Juvenile Missionary Association in London that 
equipped Hey and Ward with a camera while they stayed in London for a few days before their departure for Australia. The first photos were to be sent to these supporters. There were, however, practical problems with the glass plates and the paper. Thus, the first photographs at Mapoon were taken by a visiting boat captain who happened to call at the mission station in May 1892. He was a photography enthusiast and had all the necessary equipment on board his ship. It was part of my research project to try to identify these first photos. The Moravian Brethren did eventually begin to take photos, but not for long, as they lacked time for the cumbersome preparations necessary for the activity. Instead, their wives took over and, later, photographs of official visitations were added. Thus, the collection of historical photographs from north Queensland has a diverse and unique history.

The missionaries also collected cultural artefacts, but not on a large scale. The artefacts were sent home to Herrnhut for the local Museum of Ethnology, but were also sold to other museums and to raise money for the mission. These were mostly practical objects such as weapons, tools, baskets and ornaments, with a few exceptional ones such as message sticks, initiation girdles or bracelets made of shark vertebrae. In some but not all cases, these are accompanied by documentation or a list of artefacts. There are collections in Berlin, Dresden and, of course, in Herrnhut, which holds the majority of all collections in one museum. ${ }^{13}$

\section{Their perception of the local Aboriginal people and languages and their approach to interaction}

From the start, the Moravian missionaries in Australia were overwhelmingly confronted with unfavourable judgements of and prejudices about Aboriginal people. Some common views of Aboriginal people at that time were that they were wild and shy, treacherous and could not be trusted, and that they were cannibals. Some white Australians also believed Aborigines were not humans and had no souls, and that contact with Aborigines was dangerous so one should always carry a rifle.

13 Duplicates were also given to the museums in Frankfurt and Genk, Belgium, according to the inventory books at the Berlin Museum. 
The missionaries believed many of these stories at first; however, they had a different approach. They went to the camps unarmed trying to settle conflicts whenever they occurred. Nevertheless, they also took or used photographs to show how wild Aboriginal people had been before and how peaceful and happy they were after contact with the missionaries.

In general, however, the Moravian perception of Aboriginal people arose from a different angle than that usually applied in the wider Australian society. First, they saw Aboriginal people as human beings who had an eternal soul. (However, no one had yet prayed for their souls, which was a great concern for the missionaries.) Furthermore, they were heathens and lived in darkness. They lived a sinful life in filthy camps. They had an Old Testament kind of law: 'An eye for an eye; a tooth for a tooth.' Both Ward and Hey mention this phrase, and it is not hard to believe that they could relate to this legal system quite well. However, spiritually, the Aboriginal people lived in darkness and in fear of numerous evil spirits and devils: 'It is a religion gone mad', Hey (1912) remarked later, although he emphasised that it was still a religion.

In Hey's point of view, there was a lot of 'darkness'. ${ }^{14}$ This may sound absurd to us today considering the bright tropical conditions on Cape York Peninsula; however, it also illuminates Hey's perception of the Aboriginal way of life. It was necessary to bring some light into this darkness, which was one of the explanations for the opening of a second and third station. To light up a wide hall, one candle was not sufficient; only several would do.

\section{First interactions}

While erecting the mission house in the very first days in November 1891, Hey went to the nearby Aboriginal camp daily, establishing regular contact with the local Aboriginal people. He fed and nursed the sick and commented on his reasons for doing so. In turn, the Aboriginal people acknowledged his attention and also took care of him. He described to the Mission Board the contact situation at the Cape York mission station and wrote from Mapoon on 1 March 1892:

14 This is a recurrent phrase in his letters to the Mission Board, describing the various difficulties and failures in their attempts to Christianise Aboriginal people and to influence their beliefs. 
When I realized that my strength was fading daily, I strived to spend as much time as I could with the Blacks, as I had to tell myself that I am here because of the Blacks and the Blacks are not here because of me. I went to the camp of the Blacks every day. Initially all women and children ran away when they saw me approaching, but with small presents I soon won the children over. I also took care of the sick. An old man had a dangerous wound on his foot and I feared the worst. I cleaned and bandaged it every day as well as using an ointment I had brought with me-and after four weeks his foot was completely healed. Another man had been prevented from hunting and gathering his food by a light illness, but had been nevertheless severely weakened by it and was unable to walk. Every day I took some of our food to him and he soon recovered. These small services of love made a big difference and changed their perception, they realized that I only had the best intentions for their wellbeing in mind. I was often surprised by their tenderness when they brushed an ant or some other small animal off me or when I had to carry something, they wanted to do it for me, though there are also exceptions, which require a lot of patience. ${ }^{15}$

This letter ends with the sentence: 'Please don't forget us in far away Australia.' 16

\section{Learning the local Aboriginal language(s)}

From the start, the missionaries were keen to learn the local language(s); however, it was difficult for them to get words and they were also perplexed by the multitude of languages. ${ }^{17}$ The very first word the missionaries wanted

15 Da ich jeden Tag immer mehr merkte wie meine Kräfte dabinsanken, suchte ich so viel als möglich mit den Schwarzen in Berührung zu kommen, da ich mir sagen mußte, ich bin hier um der Schwarzen willen und die Schwarzen nicht um meinetwillen. Ich ging jeden Tag in das Lager der Schwarzen in der ersten Zeit so bald ich sichtbar wurde liefen alle Frauen und Kinder davon doch durch kleine Geschenke hatte ich bald die Kinder auf meiner Seite. Auch nahm ich mich der Kranken an ein Mann hatte eine gefährliche Wunde am Fuße ich fürchtete das Schlimste, ich unternahm jeden Tag die Reinigung der Wunde und verband es + machte gebrauch von einer Salbe welche ich bei mir hatte in 4 Wochen war der Fuß vollständig geheilt. Ein anderer Mann war durch leichtes Unwohlsein verhindert worden seiner Nahrung nach zu gehen und dadurch war er so herunter gekommen, daß er nicht mehr gehen konnte, ich brachte ihm jeden Tag von unserm Essen und auch er war bald wieder hergestellt. Solche kleinen Liebesdienste // brachten eine große Veränderung hervor, sie merkten bald daß ich nur ihr gutes im Auge habe und ich bin oft ganz erstaunt über ihre zärtlichkeit wenn eine Ameise oder sonst ein Thierchen sich an mir befindet wie sie es wegnehmen oder wenn ich etwas zu tragen habe wollen sie es für mich thun, doch giebt es auch Ausnahmen welche oft viel Geduld erfordern. Translation by Anna Kenny.

16 Letter No. 10 by Hey to the Mission Board, from Mapoon, 1 March 1892, ref. no. R.15.V.II.b.3.a.2, pp. 10 and 11, Moravian Church Archives.

17 The language spoken by the people on the Mapoon peninsula was Tjungundji. During the first 10 years of the mission, people from other language groups, such as the Thaynakwith, Mpakwithi and Yupungathi, came to live at the mission. For a discussion of Mapoon area languages, see Crowley (1981). 
to know was the word for 'heart'. In Christian belief, and especially in the Moravian belief, the heart is the organ where love and emotion-the core elements of Christianity-reside. Love and charity 'come from the heart' in Western, Christian and Moravian beliefs. Therefore, to teach Aboriginal people the Christian message, they wanted to tell them about the heart. And not only about the physical heart as such, but also about the 'good heart' and the 'bad heart'. This insistence on hearts went so far as to show pictures of a good heart and a bad heart to schoolchildren-until they were moved to tears, according to the Moravian Brethren's observations. ${ }^{18}$ One wonders whether these tears were really caused by enlightenment and wonderment, or whether the children were simply scared. Later, the missionaries changed from the 'bad heart-good heart' dichotomy to the 'bad fellow-good fellow' dichotomy-an indication that they changed from their special Moravian way of thinking and talking to the lingua franca of the area more comprehensible for the Aboriginal people.

Before Ward died in January 1895, Hey reported that Ward had given a last sermon to the Aborigines in their own language. ${ }^{19}$ Whether this is true or not we have no way of evaluating. However, Hey also mentioned that Ward had already translated the Christmas tale into the local language. Hey also points out in July 1892 —only eight months after the start of the mission station-that they were already giving all their talks and sermons in the Aboriginal language, which was a lot of work (and which was admittedly still mixed with a lot of English words). ${ }^{20}$ However, it shows their strong determination to communicate fluently in the local language. ${ }^{21}$

In 1903, Hey published his well-known 'An elementary grammar of the Nggerikudi language' as one of Roth's North Queensland Ethnography Bulletins. Hey admitted in his foreword that he still did not fully understand the language. In my opinion, Hey was considerably influenced by Walter E. Roth, an academic and medical doctor with considerable contemporary expertise in ethnographical studies. Hey saw himself

18 How these good or bad hearts were in fact depicted in the pictures, with what kind of abilities, qualities or outward appearances, we cannot know. A guess is that missionary brochures or Moravian children's books may have been used.

19 Letter No. 22 from Hey to the Mission Board, 18 January 1895, from Thursday Island, p. 8, Moravian Church Archives.

20 Letter No. 7 from Hey to Kluge, 30 July 1892, from Cullen Point, p. 7, Moravian Church Archives.

21 There is also evidence that both Ward and Hey compiled vocabularies of Tjungundji and Yupungathi during the 1890s (see Mathew 1899). 
primarily as a farmer and not as a studied man, and his attitude towards science remained reserved. Christianity was the way to understand and to interpret the world, man and nature-not science. In his later years, he stated very clearly: 'Science is knowledge, Christianity is revelation' (Hey 1912).

\section{Understanding photographs: (Hidden) messages of missionary photographs}

Snapshots were not possible in early photography, so almost all photographs in colonial and missionary times were carefully composed. These compositions were meant to consciously or unconsciously transmit messages. One important message certainly was the sheer number of people: look how many we are; a mission station at this place is worthwhile. That was an important point in arguments with politicians, local enemies of the mission or competitive missionary congregations or denominations: to document the usefulness and the popularity of a mission station at a certain locality.

Another point was the evidence that Indigenous people were willing to stand still in a row for at least some time, according to the missionaries' instructions. As mentioned above, snapshots were impossible, so people had to stand still for at least a few minutes. So, apparently, the people did what the missionaries told them to do and this was proof of the cooperation the missionaries had gained.

Another important message was the successful pacification of the area. Aboriginal people were imagined as wild, unreliable and treacherous, as discussed earlier. The missionaries had been told many times to 'never let them get behind you' or they would invariably be killed. Thus, if a missionary stood unarmed in front of Aboriginal people, with his back turned to them, he was, first, very courageous and, second, had pacified the situation successfully. 
6. GERMAN MORAVIAN MISSIONARIES ON WESTERN CAPE YORK PENINSULA

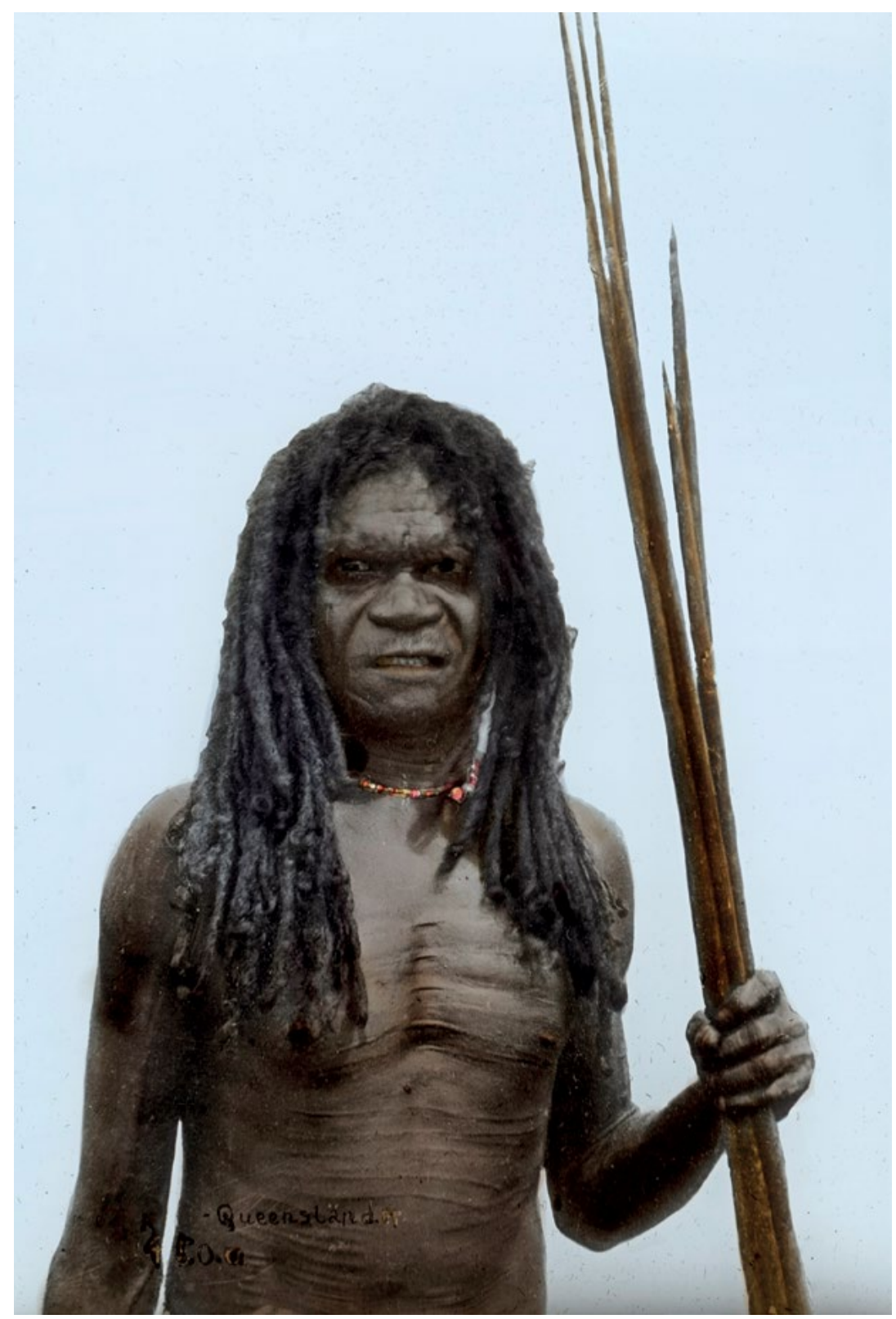

Plate 6.5 A photo often used in Moravian journals with the intention of showing European readers how Aboriginal people looked before contact with the missionaries.

Source: Collection, Moravian Church Archives, Herrnhut, Germany, LBS_00548_C_2R_58-No_59. 


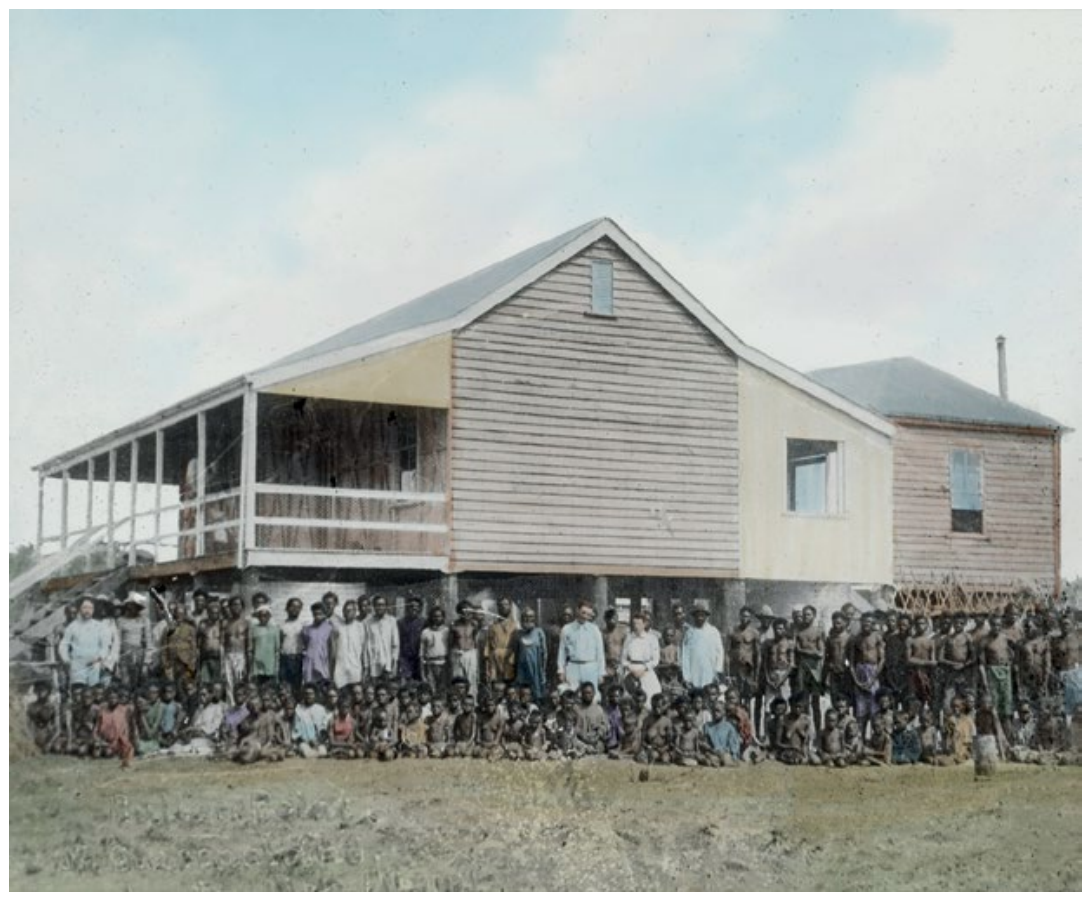

Plate 6.6 One of the first photos taken at Mapoon with a whole group of Aborigines and the missionaries standing among or in front of them.

These kinds of photos carry important and complex messages for European readers and fellow missionaries in regard to worthwhile, successful and pacificatory mission work in an imagined hostile and/or void environment.

Source: Collection, Moravian Church Archives, Herrnhut, Germany, LBS_00181_C_1R_53-No_13.

Concerning Aboriginal ceremonial life and religion there was another message to be shown in missionary photography, or, rather, in a caption that was applied later: the missionaries' perception that Aboriginal culture and religion were childish. Plate 6.7 shows dancers dressed for the crocodile dance. The brethren at Herrnhut, however, added the caption 'Heidnisches Krokodilspiel, which can be translated as 'a game of crocodiles by the heathens'. Thus, for them, this traditional ceremony was just a game. The missionaries wanted Aboriginal people to drop these 'plays' and were also opposed to traditional dance ceremonies (corroborees) of any kind, though this attitude changed later. To eliminate these 'heathenly' games, they tried to introduce other plays and (children's) games. 
6. GERMAN MORAVIAN MISSIONARIES ON WESTERN CAPE YORK PENINSULA

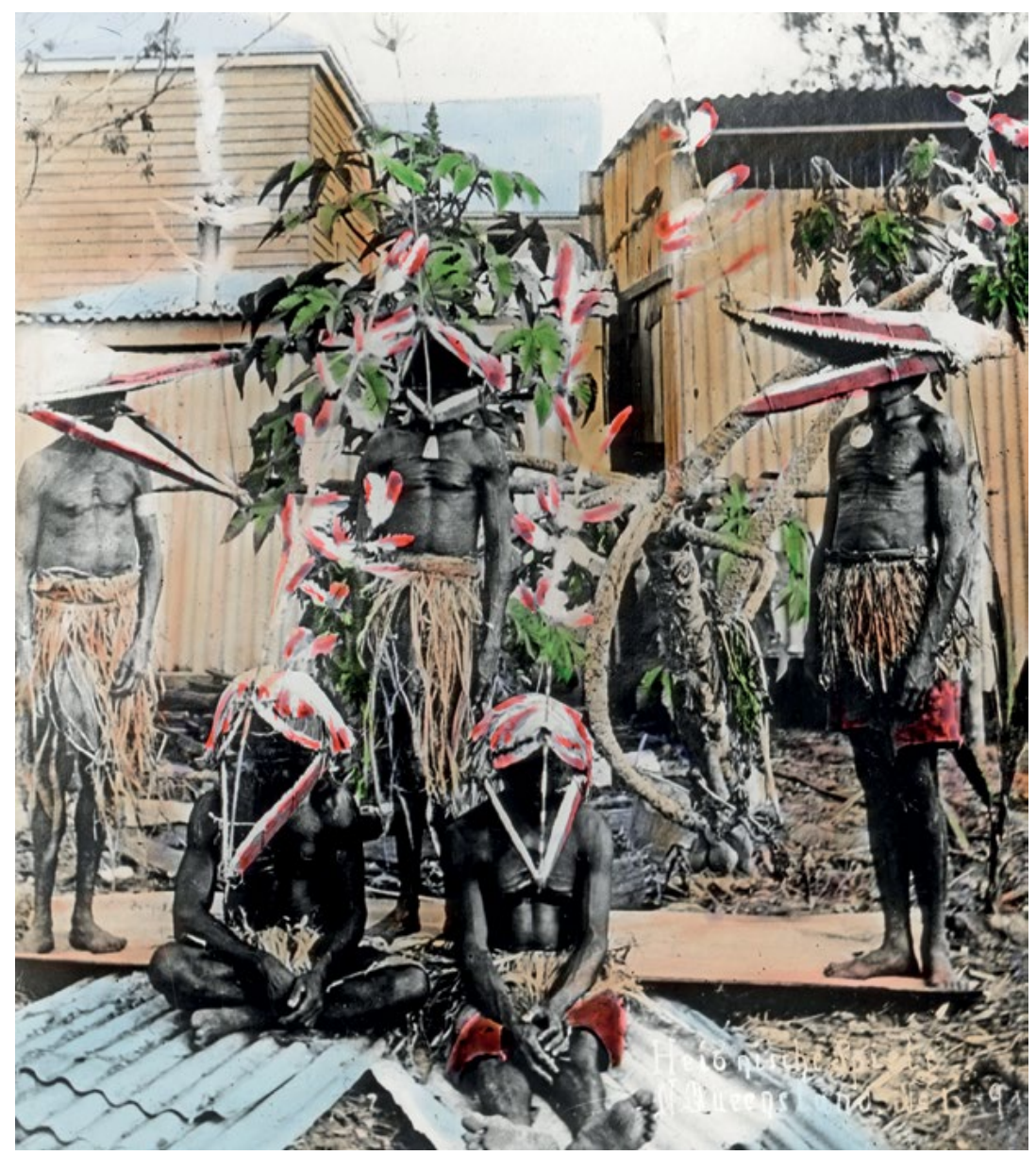

Plate 6.7 Dancers and their masks for the crocodile dance.

Such dances were often perceived by the missionaries as mere games of the heathens, not as serious choreographies with religious meanings.

Source: Collection, Moravian Church Archives, Herrnhut, Germany, LBS_01349_C_2R_56-No_20. 


\section{Understanding artefacts}

The message stick in Plate 6.9 belongs to the Australian collection at the Museum of Ethnology in Herrnhut, and is displayed in the permanent exhibition. There are no records or explanations accompanying it. However, in an article in one of the Moravian journals, I discovered the story of Aboriginal people arriving too early for Christmas at Aurukun in 1911. Christmas was very popular with Aboriginal people, as they were invited in great numbers, were given presents and received big meals for several days, so they were always eager to arrive in time. As they had no calendar to tell them when it was 24 December, they arrived at a time they hoped would be right. At Aurukun in December 1911, they arrived too early. Nothing was happening. So they left again. Arthur Richter sent them a messenger with a message stick, saying: 'Come back in seven days — then it's Christmas time.' As authorisation, he also attached a white man's envelope to the message stick, indicating that he had sent it. Aboriginal people knew that white people used paper and envelopes for messages, and the only white person in the neighbourhood was the white missionary. Thus, they could be assured that the missionary had sent this message.

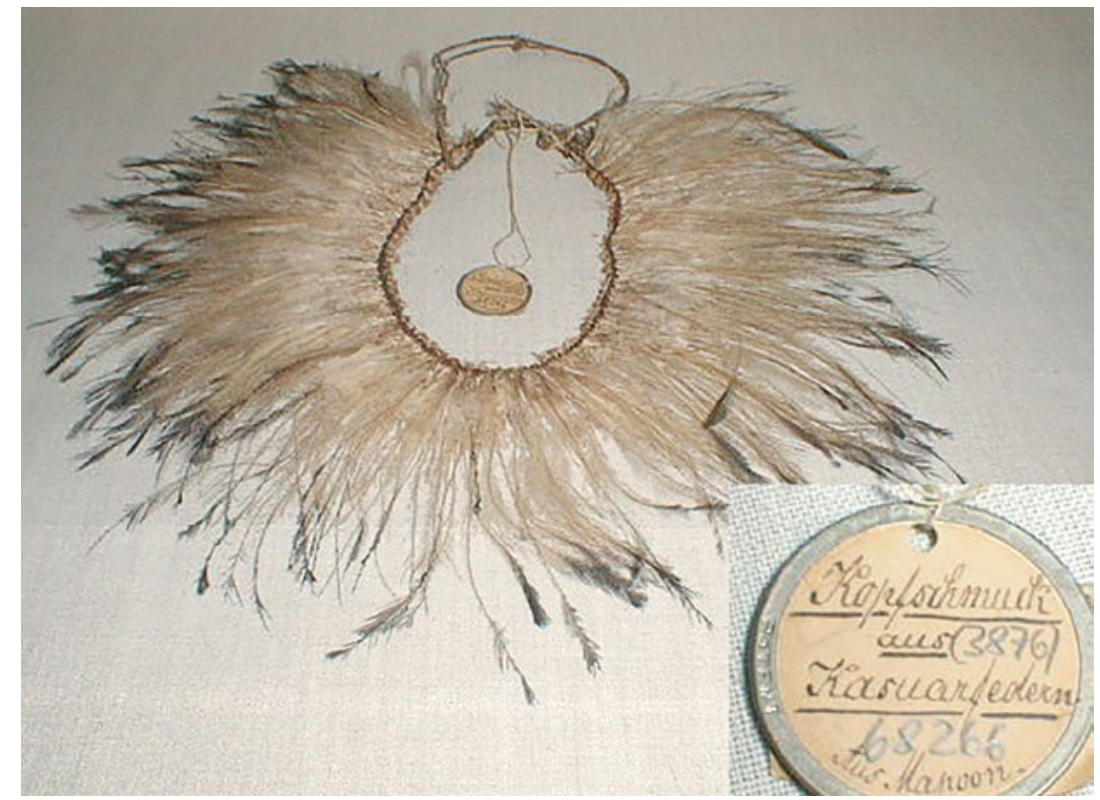

Plate 6.8 A head ornament made of cassowary feathers, from Mapoon.

Source: Inv.-No. 68266, Archives, Museum of Ethnology Herrnhut, State Art Collections, Dresden, Germany. 


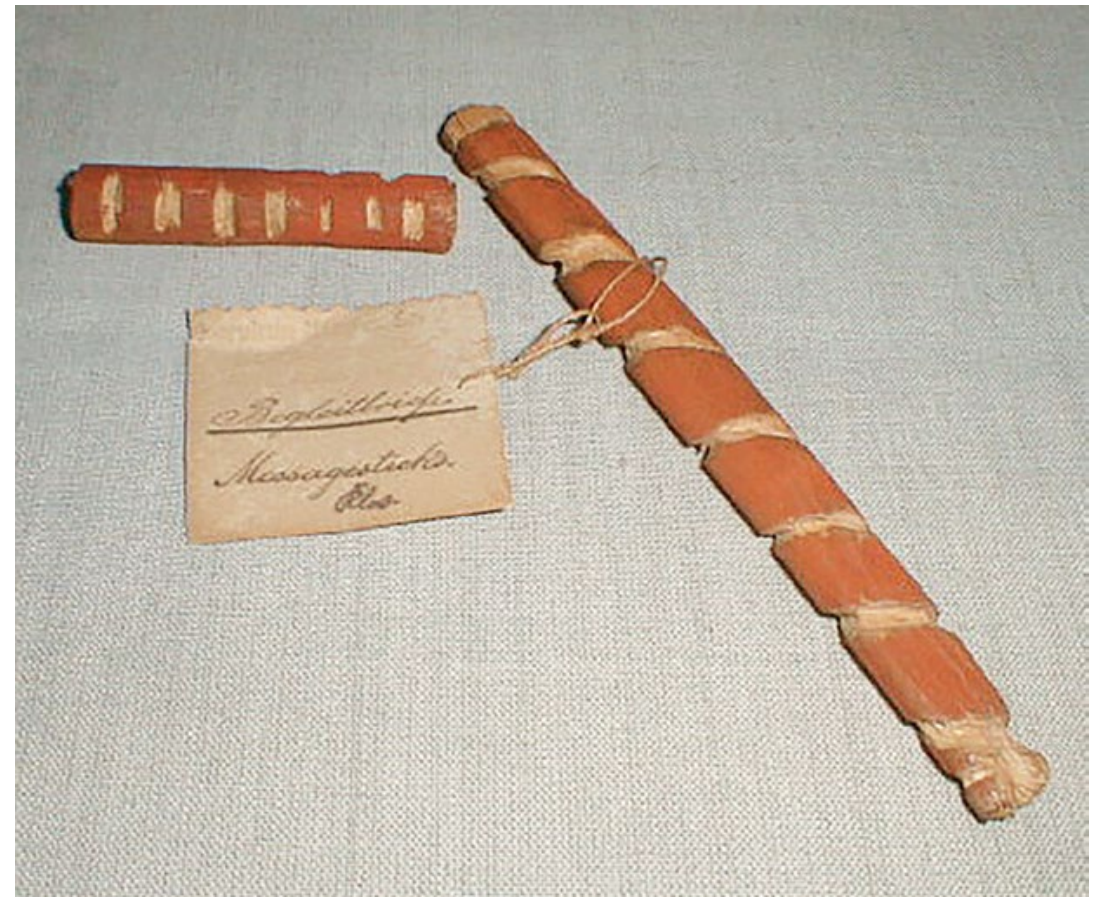

Plate 6.9 A message stick from Aurukun, probably used as a calendar to indicate the days until Christmas in 1911.

Source: Inv.-No. 68322, Archives, Museum of Ethnology Herrnhut, State Art Collections, Dresden, Germany.

\section{Understanding religion by (tin plate) names}

All Aboriginal children at the mission station had a tin plate for their food. Their names were marked at the side. However, as the missionaries explained in one of their letters, they did not have ordinary names, but the names of all kinds of animals, trees, stones and many other things. In other words, these were their totem names. The Beiblatt zur Allgemeinen Missions-Zeitschrift (Bechler 1913: 94) reported:

The boys and girls can read now, that is why there are names on the rims of their plates. But what strange/fantastical names! Dalamany, Yampa, Gaddy and others! And even more curious are the meanings of these words! Kangaroo, dog, snake, tree, stone and many other things are the meanings of these names. Not unlike the savage's view that he can gain all attributes of a person when he eats a person's body, these people believe that they are descended from the animals, stones, trees whose names they 
carry. The stronger the animal, the more powerful the tree, from which they descend, the more powerful they believe they are. This is how they perceive their beautiful names and are proud of them, similar to the ones of us, who descend from the heroes of ancient times. ${ }^{22}$

The missionaries described and understood the system of totemic ancestors well and the pride that Aboriginal people took in it, but summarised it as a question of names. Accordingly, Hey (1903), in his 'An elementary grammar of the Ngerrikudi language', explained the totem names and the totemic system as just a question of 'names' - not a question of religion.

\section{Moravian contribution to Australian anthropology: Summary and conclusion}

The Moravian archival records and museum collections are a rich source for western Cape York Peninsula anthropology. I have detailed only a few examples. The records are not accessed easily by any researcher from Germany or Australia, or by people of that region. They are written mostly in old German script and are not labelled or described adequately as ethnography as such. Neither are they translated into English or assembled in a publication under adequate titles and headings. To the contrary, the records have to be searched for among many different sources, extracted, transcribed and analysed very carefully. A sound knowledge of the Moravians' background, of the old German handwritten script and of Aboriginal people and their material culture is necessary to identify the key information that opens the door to rich anthropological data. Moreover, one has to be prepared to search in unlikely places, or under different labels, and to work through numerous archival records written in old German. The results, however, are very rewarding and can be used for very fruitful research and study in the future.

22 Jetzt können Buben und Mädchen lesen, darum stehen jetzt Namen auf dem Tellerrand. Aber was für wunderliche Namen! Dalamany, Yampa, Gaddy und andere! Und noch viel wunderlicher die Bedeutung dieser Worte! Das Känguruh, Hund, Schlange, Baum, Stein und mancherlei andere Dinge, das ist die Bedeutung der verschiedenen Namen. Wie das Menschenfressen darin seinen Grund hat, daß der Wilde der Meinung ist, er könnte mit dem Leibe auch die Seele seines Opfers mit all ibren Tugenden und Vorzügen in sich aufnehmen, glauben diese Leute den Tieren, Steinen, Bäumen, deren Namen sie durchs Leben tragen, abzustammen. Je stärker das Tier, je mächtiger der Baum ist, von der er seine Herkunft ableiten kann, um so kraftvoller dünkt sich der Mensch. So sehen sie auf ihre schönen Namen und füblen sich stolz in deren Besitz, ähnlich wie bei uns alle die, welchen ihren Stammbaum von Helden grauer Vorzeit herleiten. Translation by Anna Kenny. 


\section{References}

Bechler, T. 1913. Kulturarbeit der Brüdergemeine in Nordaustralien. Ein Kabinettstück neuerer Missionsgeschichte. Beiblatt zur Allgemeinen Missions-Zeitschrift 40(Jhg., 11)(Heft No. 6)(November).

Crowley, T. 1981. The Mpakwithi dialect of Anguthimri. In Handbook of Australian Languages. Volume 2, (eds) R. M. W. Dixon and B. J. Blake, pp. 146-94. Canberra: Australian National University Press. doi.org/10.1075/z.hal2.07cro.

Darwin, C. 1859. On the Origin of Species by Means of Natural Selection, or the Preservation of Favoured Races in the Struggle for Life. London: John Murray.

Erckenbrecht, C. 2010. Auf der Suche nach den Ursprüngen. Die Australienreise des Anthropologen und Sammlers Hermann Klaatsch 1904-1907. Ethnologica N.F. 27.

Hagenauer, F. A. 1886. Notes of a missionary journey to north Queensland. Special print.

Hey, N. 1903. An elementary grammar of the Nggerikudi language. In North Queensland Ethnography Bulletin, No. 6, (ed.) W. Roth. Brisbane: Department of Public Lands.

Hey, N. 1912. Substance of an address delivered by missionary N. Hey on 'Foreign mission night' during the sitting of the Presbyterian General Assembly of Queensland, May 14th 1912. Typed manuscript in Hey's personal file, ref. no. MD 925, Moravian Church Archives, Herrnhut, Saxony.

Huxley, T. H. 1863. Man's Place in Nature. Ann Arbor: University of Michigan Press.

Jensz, F. 2007. Collecting cultures for God: German Moravian missionaries and the British colony of Victoria, Australia, 1848-1908. PhD thesis. School of Historical Studies, Faculty of Arts, University of Melbourne, Melbourne. 
Jensz, F. 2012. Collecting cultures: Institutional motivations for nineteenth-century ethnographical collections formed by Moravian missionaries. Journal of the History of Collections 24(1): 63-76. doi.org/ 10.1093/jhc/fhq043.

Kidd, R. 1997. The Way We Civilise: Aboriginal affairs—The untold story. Brisbane: University of Queensland Press.

Mathew, J. 1899. Eaglehawk and Crow: A study of the Australian Aborigines, including an inquiry into their origin and a survey of Australian languages. London: D. Nutt.

Meißel, G. 1898. Lebenslauf des verheirateten Bruders Gottlieb Meißel, heimgegangen in Niesky am 27. Juni 1897. Mitteilungen aus der Brüder-Gemeine zur Förderung christlicher Gemeinschaft (2)(S): 59-98.

Missionsdirektion (eds). 1895. Missions-Atlas der Brüdergemeine. Herrnhut: Mission Board.

Missionsdirektion (eds). 1907. Missions-Atlas der Brüdergemeine. Herrnhut: Mission Board.

Moravian Church Archives. n.d. Letters Nos 1-16 from Hey to Kluge, ref. no. NKH 9, Moravian Church Archives, Herrnhut, Saxony.

Moravian Church Archives. n.d. Letters Nos 5-22 from Hey to the Mission Board, ref. no. R.15.V.II.b.3.a.2, Moravian Church Archives, Herrnhut, Saxony.

Moravian Church Archives. n.d. Letters Nos 46-70 from Ward to the Mission Board, ref. no. R.15.V.II.b.3.a.2, Moravian Church Archives, Herrnhut, Saxony.

Moravian Missionary Reporter and Illustrated Missionary News. 1893. [London.] Vol. III(8)(NS)(August): 59.

Roth, W. E. 1903. Superstition, magic, and medicine. North Queensland Ethnography Bulletin, No. 5. Brisbane: Government Printer.

Schoetensack, O. 1901. Die Bedeutung Australiens für die Heranbildung des Menschen aus der niederen Form. (Vorgelegt in der Sitzung der Berliner Anthropologischen Gesellschaft vom 27. Juli 1901.) Zeitschrift für Ethnologie 33(S): 127-54. 
Schoetensack, O. 1902. Erläuternde Bemerkungen zu meiner Abhandlung 'Über die Bedeutung Australiens für die Heranbildung des Menschen aus einer niederen Form'. Verhandlungen der Berliner Anthropologischen Gesellschaft, 34(S): 105.

Schoetensack, O. 1904. Die Bedeutung Australiens für die Heranbildung des Menschen aus einer niederen Form. Verhandlungen des naturhistorisch-medizinischen Vereins zu Heidelberg 7(S): 105-30. 
This text is taken from German Ethnography in Australia, edited by Nicolas Peterson and Anna Kenny, published 2017 by ANU Press, The Australian National University, Canberra, Australia.

dx.doi.org/10.22459/GEA.09.2017.06 